\title{
PREPARATION, CHARACTERIZATION AND PERFORMANCE STUDIES OF ACTIVE PVDF ULTRAFILTRATION-SURFACTANTS MEMBRANES CONTAINING PVP AS ADDITIVE
}

\author{
(Penyediaan, Pencirian dan Kajian Prestasi PVDF Aktif Ultraturasan-Surfaktan Membran \\ mengandungi PVP sebagai Bahan Tambahan)
}

\author{
Nur Izzah Md Fadilah and Abdul Rahman Hassan* \\ Industrial Membrane Technology Laboratory, \\ Department of Industrial Chemical Technology, \\ Faculty of Science and Technology, \\ Universiti Sains Islam Malaysia, 71800 Nilai, Negeri Sembilan, Malaysia \\ *Corresponding author: abdrahman@usim.edu.my
}

Received: 24 February 2015; Accepted: 27 October 2015

\begin{abstract}
The role of surfactants in the formation of active Poly(vinylidene fluoride) (PVDF) ultrafiltration (AUF) membranes was studied. The effect combination of surfactants that are Sodium dodecyl sulfate (SDS)/Tween 80 and Tween 80/Triton X-100 formulations on performance and morphological structures were investigated for the first time. The influence of surfactants blends on the membrane pores was also examined. Experimental data showed that combination of Tween 80/Triton X-100 give the highest BSA permeation flux with a value of $285.51 \mathrm{Lm}^{-2} \mathrm{~h}^{-1}$. With combination of SDS/Tween 80 , the AUF membrane showed the highest protein rejection up to $93 \%$ and $79 \%$ for Bovine Serum Albumin (BSA) and Egg Albumin (EA), respectively. Moreover, membranes characterization demonstrated that the addition of SDS/Tween 80 and Tween $80 /$ Triton X100 were found to affect the performance, surface morphologies and membrane pores of AUF PVDF membranes.
\end{abstract}

Keywords: poly(vinylidene fluoride), ultrafiltration, surfactant, protein rejection, morphology

\section{Abstrak}

Peranan surfaktan dalam pembentukan ultraturasan PVDF aktif (AUF) membran telah dikaji. Gabungan kesan surfaktan iaitu SDS/Tween 80 dan Tween 80/Triton X-100 formulasi terhadap prestasi dan struktur morfologi telah dikaji buat pertama kali. Pengaruh adunan surfaktan pada liang membran juga diperiksa. Data ujikaji menunjukkan bahawa gabungan Tween $80 /$ Triton $\mathrm{X}-$ 100 memberikan bacaan penyerapan fluks tertinggi iaitu $285.51 \mathrm{Lm}^{-2} \mathrm{~h}^{-1}$. Dengan kombinasi SDS/Tween 80, membran AUF menunjukkan protein penolakan tertinggi sehingga $93 \%$ dan $79 \%$ masing - masing untuk Albumin Serum Bovine (BSA) dan Albumin Telur (EA). Selain itu, membran pencirian menunjukkan bahawa penambahan SDS/Tween 80 dan Tween $80 /$ Triton X100 didapati memberi kesan kepada prestasi, morfologi permukaan dan liang membran AUF PVDF.

Kata kunci: poli(vinylidene fluorida), ultraturasan, surfaktan, penolakan protein, morfologi

\section{Introduction}

Membrane technology has been found to be an alternative and attractive approach for separation or filtration because the process is faster, energy efficient and does not involve any phase change. Currently, the application of ultrafiltration (UF) in membrane technology is growing very rapidly in protein separations. The important goal in membrane technology is to control the membrane structure, which affects its performance. Hence, extensive 


\section{Nur Izzah \& Abdul Rahman: PREPARATION, CHARACTERIZATION AND PERFORMANCE STUDIES OF ACTIVE PVDF ULTRAFILTRATION-SURFACTANTS MEMBRANES CONTAINING PVP AS ADDITIVE}

research has been conducted in attempting to improve the performance of the membrane [1]. Since Loeb and Sourirajan first introduced the phase inversion method, considerable progress has been made for understanding the formation mechanism of asymmetric membranes. The phase inversion process induced by immersion precipitation is a well-known technique to prepare asymmetric polymeric membranes. In that technique, a thin film of polymer solution is cast on to a suitable substrate and subsequently immersed into a coagulation bath. The diffusion exchange of solvent and non-solvent will results in the phase separation and also formation of membrane [2].

The UF membrane structure and performance can be controlled by the casting solution composition, casting condition and coagulation bath composition. Thus, in order to get the membrane with excellent structure and performance, introduction of a suitable additive to the casting solution is a convenient and efficient method [3]. Several researchers have reported on the role of additives in the membranes structure and performance. Some additives have the tendency to form macrovoids, others help in suppressing the macrovoids improving interconnectivity of the pores and resulting in higher porosity in the top layer and sub layer. In this study, Polyvinylpyrolidone (PVP) was used as an additive with combination of surfactants in order to control the membrane performance in the preparation of UF membranes. PVP is known as a non-toxic material which miscibility with membrane and solubility in water as well as solvents make PVP a suitable polymer additive. During the membrane formation process, PVP is added to the polymer solution to promote the formation of micropores [4]. It is assumed that the hydrophilic additive, PVP dissolve in water and the sites where PVP exist become micropores during the phase inversion process. Besides the formation of micropores, it has been generally accepted that the porosity increases and the macrovoid formation disappears as PVP was added to the casting solution [5]. For instance, Xu et al. [6] studied the effect of PVP for different MW on the morphology of polyetherimide hollow fiber and they found that the higher the MW of PVP added, bigger the pores were formed [6]. On the other hand, Wang et al. [7] also found similar finding that the decrease in the concentration of PVP resulted to lower water flux and higher rejection.

Although it appears that a number of works has been reported [5-7] using PVP as additives, there is yet no report regarding the effect of PVP additives with combination of surfactants on the morphology and performance of PVDF membranes. The surfactants need to be introduced in the casting solutions in order to prepare membranes either with good membrane structure (consisting of finger-like, dense top-layer and spongy sub-layer) or penetration properties because the addition of additive is still not versatile enough to prepare the appropriate membrane structure and properties. In this paper, the asymmetric membranes were prepared using polymeric solutions consisting of the PVDF, solvent N-methyl-2-pyrrolidon (NMP) and PVP by classical phase inversion method. By combining of surfactant to the polymeric solutions, the effect of anionic and non-ionic surfactants on morphological and performance of the asymmetric membranes such as pure water permeations and rejections were investigated and discussed.

\section{Materials}

\section{Materials and Methods}

Poly(vinylidene fluoride) (PVDF, Kynar® from Arkema, MW $=45.00 \mathrm{~g} / \mathrm{mol}, \mathrm{d}=1.78 \mathrm{~g} / \mathrm{cm} 3$ ) was obtained in pellet form, which is used as polymer in the preparation of membrane casting solution. N-methyl-2-pyrrolidone (NMP, >99\%) (Merck, Darmstadt, Germany, $\mathrm{d}=1.00 \mathrm{~g} / \mathrm{cm}^{3}$ ) was used as the solvent for PVDF. Polyvinylpyrolidone (PVP) (MW = 58000 g/mol, K29-32 from Acros Organics), was used as additive in the dope solution. Sodium dodecyl sulfate (SDS) (MW $=288.37 \mathrm{~g} / \mathrm{mol}$, Merck Schuchardt OHG, Germany), Triton X-100 $(\mathrm{MW}=646.86 \mathrm{~g} / \mathrm{mol}$, Fisher Chemical $)$ and Tween $80\left(\mathrm{~d}=1.060-1.090 \mathrm{~g} / \mathrm{cm}^{3}\right.$, Merck Schuchardt OHG, Germany) were used as surfactants in the casting solutions. Other solvents such as ethanol and n-hexane as well as distilled water were used as non-solvent in the coagulant bath. Bovine serum albumin (BSA), MW $=69 \mathrm{kDa}$ and egg albumin (EA), MW = $45 \mathrm{kDa}$ were purchased from Acros Organics, USA, used as the solute for filtration experiments. Disodium phosphate dehydrate $\left(\mathrm{Na}_{2} \mathrm{HPO}_{4} \cdot 2 \mathrm{H}_{2} \mathrm{O}\right)$ and sodium dihydrogen phosphate $\left(\mathrm{NaH}_{2} \mathrm{PO}_{4} \cdot \mathrm{H}_{2} \mathrm{O}\right)$ were used for the preparation of protein feed solution.

\section{Preparation of membranes}

Flat-sheet type PVDF membranes were prepared by the immersion precipitation method at room temperature. The casting solutions were prepared by blending of PVDF and PVP in the presence of different types of surfactant in 
NMP under constant stirring for $8 \mathrm{~h}$ at $60^{\circ} \mathrm{C}$. A series of polymer solutions were prepared by various composition and type of surfactants, designated as M-P, M-PST and M-PTT as shown in Table 1. The obtained homogenous solution was allowed to stand for at least $2 \mathrm{~h}$ to eliminate the air bubbles. Subsequently, the solution was spread uniformly on a glass plate, with the help of a casting knife maintaining a clearance between the knife and the plate. The polymer solutions were cast into thin film $(100 \mu \mathrm{m}$ thick) on glass sheets and then the resulting films were immersed into a water bath immediately and let the precipitation to complete (about 2-4 mins). The colour of the casted films changed from transparent to white immediately after immersion into the coagulation bath and separates out of the glass plate after some-time (3-5s). The formed membranes were immersed into tap water for 1 day. The dry membranes were obtained by soaking with ethanol and n-hexane for 24 hour and 1-3 hours respectively before drying at room temperature. Finally, the sheets were cut into the form of circular disk with diameter of $42 \mathrm{~mm}$ to be fitted in the membrane cell for filtration experiments. Two types of phase separation can be distinguished in the membrane preparation process. Firstly, the dry phase inversion takes place in the atmosphere by evaporation of the solvent. Secondly, the wet phase inversion is carried out by immersing the polymer solution film into a coagulation bath of a non-solvent, where an exchange of solvent and non-solvent takes place and the membrane is formed. Hence, in this study, we prepared membranes by a combination of both processes.

Table 1. The composition of dope formulation AUF membranes

\begin{tabular}{ccccccc}
\hline \multirow{2}{*}{ Membrane } & $\begin{array}{c}\text { Total polymer } \\
(\mathbf{w t} \%)\end{array}$ & $\begin{array}{c}\text { Solvent } \\
(\mathbf{w t} \%)\end{array}$ & $\begin{array}{c}\text { Additive } \\
(\mathbf{w t} \%)\end{array}$ & \multicolumn{3}{c}{$\begin{array}{c}\text { Surfactants } \\
(\mathbf{w t} \%)\end{array}$} \\
\cline { 2 - 8 } & PVDF & NMP & PVP & SDS & Triton X-100 & Tween 80 \\
\hline M-P & 17 & 80 & 3 & - & - & - \\
M-PST & 17 & 78 & 3 & 1 & - & 1 \\
M-PTT & 17 & 78 & 3 & - & 1 & 1 \\
\hline
\end{tabular}

\section{Pure water permeation (PWP)}

Membranes after compaction were subjected to pure water permeation (PWP) within the range operating pressure of $50-300 \mathrm{kPa}$. The PWP was measured to ensure that the membranes used were stable. The permeability was measured under steady state flow. The PWP in the permeate side was measured at the ambient temperature of $25 \pm$ $1{ }^{\circ} \mathrm{C}$. The pure water permeation, $J_{w}$ was determined using Equation (1).

$$
J_{W}=\frac{Q}{A \times t}
$$

where $J_{w}=$ pure water permeation $\left(\mathrm{Lm}^{-2} \mathrm{~h}^{-1}\right) ; \mathrm{Q}=$ Volume of permeate $(\mathrm{L}) ; \mathrm{A}=$ membrane area $\left(\mathrm{m}^{2}\right) ; \mathrm{t}=\mathrm{time}(\mathrm{h})$

\section{Protein rejection studies}

Ultrafiltration experiment was conducted in the batch kit cell mentioned to study the influence of the addition of additives and surfactants on solute rejection of the prepared membranes. Bovine serum albumin (BSA, $69 \mathrm{kDa}$ ) and egg albumin (EA, $45 \mathrm{kDa}$ ) were chosen for the estimation solute rejectio $\mathrm{n}$. The protein solutions was prepared at a concentration of $0.1 \mathrm{wt} \%$ in a phosphate buffer $(0.5 \mathrm{M}, \mathrm{pH} 7.2)$ using distilled water and was filtered through each of membranes. During the UF process, the permeate protein concentration were collected over measured time intervals in graduated tubes, and were analyzed for protein content by using UV-Visible spectrophotometer at a wavelength of $280 \mathrm{~nm}$. The percentage rejection was calculated using Equation (2).

$$
R(\%)=\left(1-\frac{C_{p}}{C_{f}}\right) \times 100
$$




\section{Nur Izzah \& Abdul Rahman: PREPARATION, CHARACTERIZATION AND PERFORMANCE STUDIES OF ACTIVE PVDF ULTRAFILTRATION-SURFACTANTS MEMBRANES CONTAINING PVP AS ADDITIVE}

where $\mathrm{R}$ is percentage rejection of protein $(\%) ; \mathrm{C}_{p}$ is concentration of protein in permeate $(\mathrm{mg} / \mathrm{mL}) ; \mathrm{C}_{f}$ is concentration of protein in feed $(\mathrm{mg} / \mathrm{mL})$.

\section{Membrane Characterization by Morphological Studies}

The morphology of the prepared membranes were investigated by microscopic observations which is carried out by a scanning electron microscope (SEM-JEOL JSM-6360LA) to provide the visual information of the top surface as well as cross-sectional morphology of the membranes. The top surface and cross-sectional views of the membranes should be broken in liquid nitrogen and coated with gold by using Auto Fine Coater (JFC-1600). All the SEM images were taken at various magnifications (X400-500). The top of the cross-section photographs presented in this article is the skin layer of the membrane.

\section{Ultrafiltration test analysis}

\section{Results and Discussion}

Ultrafiltration experiments were performed to explore the performance of PVDF/PVP additives membrane with addition of anionic/non-ionic and non-ionic/non-ionic surfactants. The water flux or pure water permeation (PWP), $J_{w}$ of prepared membranes was measured to evaluate the influence of membrane composition on the membrane permeability. Figure 1 shows the pressure-dependent fluxes of pure water for the membranes prepared. PWP of all modified membranes were increases gradually with pressure increased up to $300 \mathrm{kPa}$.

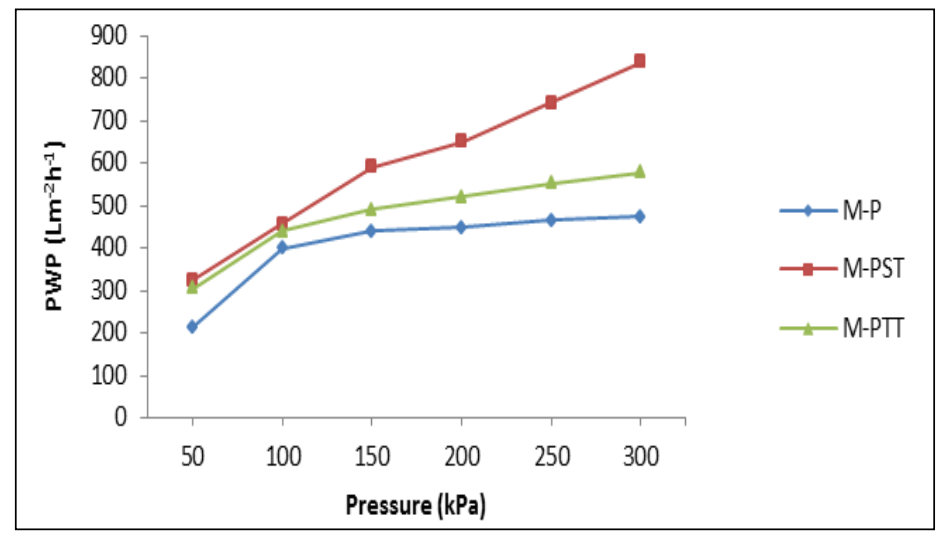

Figure 1. Effect of combination anionic/non-ionic and non-ionic/non-ionic surfactants on pure water permeation (PWP) of PVDF membranes

The combination of anionic and non-ionic surfactants, M-PST exhibited a higher PWP than that of the M-P and MPTT membranes. From the result obtained, PWP of the M-PST attained a maximum value of $838.11 \mathrm{Lm}^{-2} \mathrm{~h}^{-1}$, while the minimum value was just $472.39 \mathrm{Lm}^{-2} \mathrm{~h}^{-1}$ for the M-P at $300 \mathrm{kPa}$. The water flux variation can be explained as the incorporation of combination anionic with non-ionic surfactants enhanced the hydrophilicity of the membranes which improved the water permeation to a certain extent. In the other hand, the value of PWP for M-PTT was found to be $577.37 \mathrm{Lm}^{-2} \mathrm{~h}^{-1}$, which is higher than M-P. This is correlates with the combination of both non-ionic surfactants resulted in high hydrophilicity compared to membranes without surfactant.

\section{Protein permeate flux studies}

The highest BSA permeate flux (PF) was $285.51 \mathrm{Lm}^{-2} \mathrm{~h}^{-1}$ for the M-PTT membrane and the minimum BSA-PF was $151.72 \mathrm{Lm}^{-2} \mathrm{~h}^{-1}$ for the M-P-without surfactant membrane (Figure 2). The highest PF is due to the formation of macrovoids in the sub-layer membrane which is faster rated leaching out during immersion process. Besides, for the combination non-ionic/non-ionic surfactants, interaction between hydrophobic chain and the non-polar sites of the membranes were observed which leading to hydrophilization of the membrane surface and pores [8]. As a result, higher PF for the non-ionic/non-ionic surfactants solution are obtained. In the other hand, the lowest PF may be due 
to immiscible phase behaviour of blend composition without surfactant, which predominates due to lower molecular attractive forces between its blend components. During the filtration process, certain protein molecules can be deposited on the membrane surface, which caused an abrupt drop in flux. Additionally, protein molecules can be swept from the surface due to stirring, which resulted in equilibrium between depositions and sweeping [9].

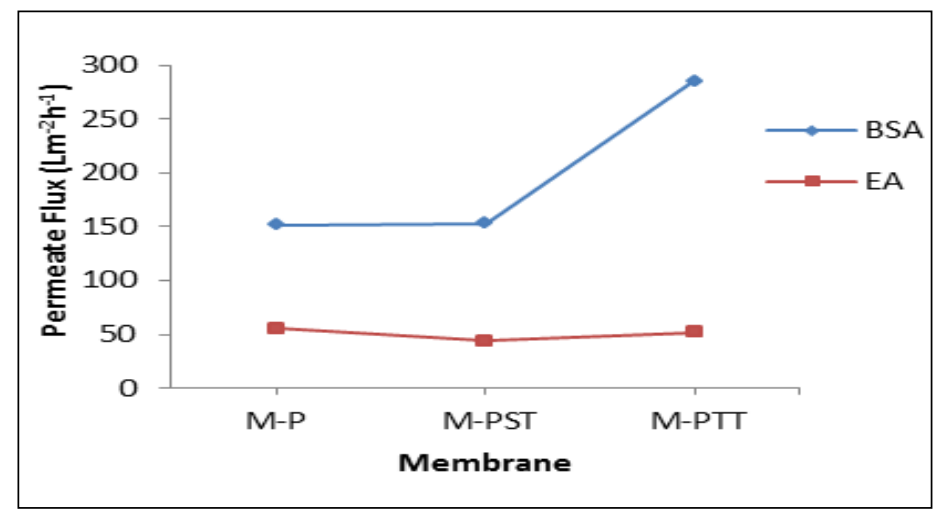

Figure 2. Effect of combination anionic/non-ionic and non-ionic/non-ionic surfactants on permeate flux (PF) of protein BSA and EA

\section{Protein rejection}

The performance of the prepared UF membranes is also measured by investigating protein rejection during filtration experiment with macromolecular solute BSA $(69 \mathrm{kDa})$ and EA $(45 \mathrm{kDa})$ solution as feed. The protein rejection of BSA and EA are illustrated in Figure 3 for all the modified membranes when the feed solution is maintained at pH 7.2 , since a change in $\mathrm{pH}$ may increase the adsorptive fouling of the membranes. In addition, if the $\mathrm{pH}$ of the proteins solution changes, intermolecular forces between protein molecules and membranes will predominate and affect the efficiency of membranes [10]. From the result obtained, the M-PST membrane exhibited higher rejection up to $93 \%$ and $79 \%$ for BSA and EA respectively, compared with other membranes. Higher rejection of BSA may be due to larger solute size of BSA compared with EA. Besides, the M-PTT membrane which combine non-ionic with non-ionic surfactants showed the BSA rejection $90 \%$, lower than membrane which combine ionic with nonionic surfactants, may be because of homogeneity between the surfactants in the polymer solution. This will resulted in the formation of aggregate pores in membranes as discussed in SEM analysis.

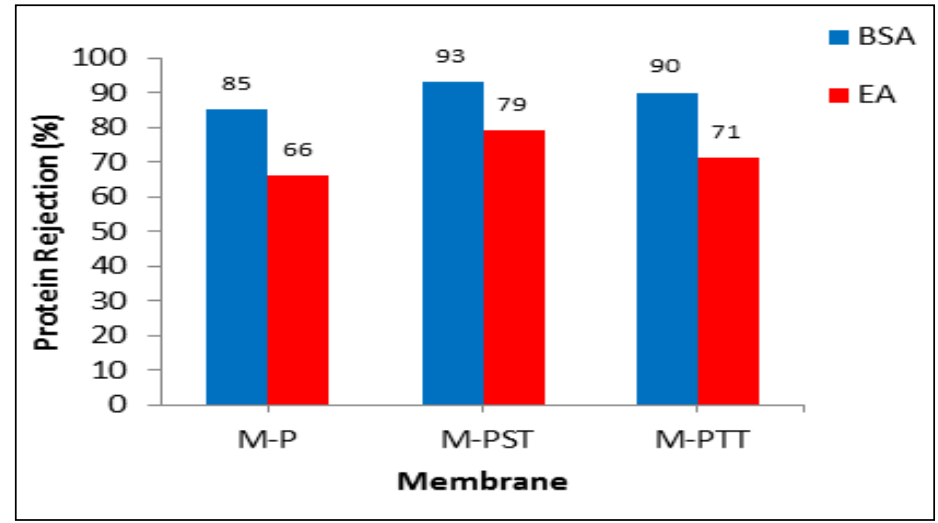

Figure 3. Effect of combination anionic/non-ionic and non-ionic/ non-ionic surfactants on proteins rejection 


\section{Nur Izzah \& Abdul Rahman: PREPARATION, CHARACTERIZATION AND PERFORMANCE STUDIES OF ACTIVE PVDF ULTRAFILTRATION-SURFACTANTS MEMBRANES CONTAINING PVP AS ADDITIVE}

\section{SEM analysis}

Figure 4 shows the SEM images of the cross-section for different membranes prepared with combination of anionic/non-ionic and non-ionic/non-ionic surfactants. The SEM image of M-P membrane as presented in Figure 4 (a) shows the larger (open) finger-like pores formed were influenced by the exchange time between solvent and non-solvent in the coagulation bath [11]. It may be seen from the figures that membranes formed are having short and finger-like structures from the top layer to middle of sub-layer of the membrane. A dense spongy structure also formed beneath the skin layer and porous sub-layer of PVDF membrane. The casting solutions provided from hydrophobic polymers produced sponge-like structures due to delayed phase separation occurred during phase inversion process [12].

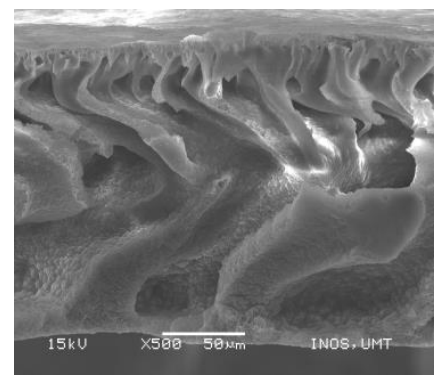

(a) M-P

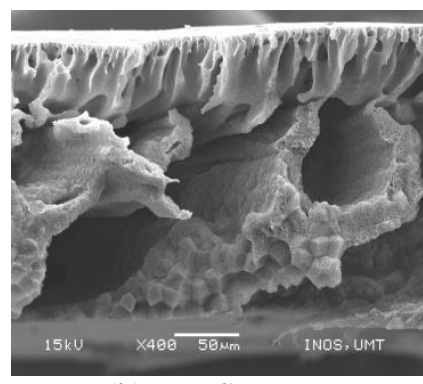

(b) M-PST

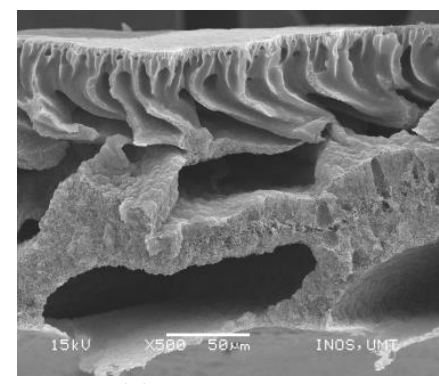

(c) M-PTT

Figure 4. Cross-section SEM micrographs of morphological structure of PVDF membrane prepared withcombination anionic/non-ionic and non-ionic/non-ionic surfactants

The SEM images of M-PST and M-PTT in Figure 4(b) and (c) respectively show the existence of macrovoids in the presence of combination anionic and non-ionic surfactants in the PVDF/NMP blend membranes. Both of these membranes had asymmetric structure consisting of a fine porous selective barrier and a much thicker porous sublayer. The SEM images in Figure 4(b) and (c) indicate that the combination of small amount SDS/Tween 80 and Triton X/tween 80 respectively in the casting solution can incite macrovoids formation.

A dense top layer and a porous sub-layer that is occupied by closed cell within polymer matrix and finger-like pore as well as interaction of anionic together non-ionic surfactants as shown clearly in Figure 4(b). Obviously, large pores are formed in the sub-layer of the membranes and therefore, it can be explained by miscibility between the added ionic, non-ionic surfactants and the coagulant. The miscibility between surfactant and coagulant plays an important role in the formation process of various sizes of pores. The macrovoids and finger-like pores in the sublayer can be induced or suppressed by addition of appropriate surfactants, depending on their miscibility with coagulants. The addition of surfactants that have high miscibility with coagulants may be able to extend the formation of finger-like pores and macrovoids. On the other hand, the addition of surfactants with low miscibility with coagulants suppresses the macrovoids formation [13].

\section{Conclusion}

This study shows that all the membranes have asymmetric structure as observed from SEM images. It was found out that the combination of small amounts ionic surfactant (i.e. SDS) and non-ionic surfactants (i.e. Tween 80 and Triton X) to the casting solution increases formation of macrovoids and finger-like pores in the sub-layer of the membranes. With this little addition of surfactants to the casting solutions, the thickness of the prepared membranes significantly increases and hence, probably enhanced the PWP to a maximum value of $838.11 \mathrm{Lm}^{-2} \mathrm{~h}^{-1}$ and $93 \%$ for BSA protein rejection. 


\section{Acknowledgement}

The authors are grateful and acknowledge the Ministry of Education of Malaysia and Industrial Membrane Technology Lab, USIM for the support and contribution on this study.Besides, the authors would like to thank the Research Management Centre (RMC), Universiti Sains Islam Malaysia (USIM) to finance the project under the Fundamental Fund.

\section{References}

1. Idris, A., Zain, N. M. and Yusof, N. M. (2007). Synthesis, characterization and performance of asymmetric Polyethersulfone (PES) ultrafiltration membranes with polyethylene glycol of different molecular weights as additives. Desalination, 207:324 - 339 .

2. Zuo, D. Y., Xu, Y. Y., Xu, W. L. and Zou, H. T. (2008). The influence of PEG molecular weight on morphologies and properties of PVDF asymmetric membranes. Chinese Journal of Polymer Science, 26: 405 414.

3. Zhao, S., Wang, Z., Wei, X., Tian, X., Wang, J., Yang, S. and Wang, S. (2011). Comparison study of the effect of PVP and PANI nanofibers additives on membrane formation mechanism, structure and performance. Journal of Membrane Science, 385: 110 - 122.

4. Ismail, A. F. and Hassan, A. R. (2007). Effect of additive contents on the performances and structural properties of asymmetric Polyethersulfone (PES) nanofiltration membranes. Separation and Purification Technology, 55: 98 - 109 .

5. Jung, B., Yoon, J. K., Kim, B. and Rhee, H. W. (2004). Effect of molecular weight of polymeric additives on formation, permeation properties and hypochlorite treatment of asymmetric polyacrylonitrile membranes. Journal of Membrane Science, 243: 45 - 57.

6. Xu, Z. L., Chung, T. S. and Huang, Y. (1999). Effect of polyvinylpyrroli-done molecular weights on morphology, oil/water separation, mechanical and thermal properties of polyetherimide/ polyvinylpyrrolidone hollow fiber membranes. Journal of Applied Polymer Science, 74: 2220 - 2233.

7. Wang, D., Li, K. and Teo, W. K. (1999). Preparation and characterization of polyvinylidene fluoride (PVDF) hollow fiber membranes. Journal of Membrane Science, 163: $211-220$.

8. Fernandez, E., Benito, J. M., Pazos, C. and Coca, J. (2005). Ceramic membrane ultrafiltration of anionic and non-ionic surfactant solutions. Journal of Membrane Science, 246:1 - 6.

9. Sun, C. (2009). Poly(vinylidene fluoride) membranes: preparation, modification, characterization and applications. University of Waterloo, Waterloo, Ontario, Canada.

10. Arthanareeswaran, G., Thanikaivelan, P., Srinivasn, S., Mohan, D. and Rajendran, M. (2004). Synthesis, characterization and thermal studies on cellulose acetate membranes with additive. Journal of European Polymer, 40: 2153 - 2159.

11. Rahimpour, A., Madaeni, S. and Mehdipour-Atei, S. (2008). Synthesis of a novel poly(Amide-Imide) and preparation and characterization of PAI blended Polyethersulfone (PES) membrane. Journal of Membrane Science, 311: $349-359$.

12. Ghasem, N., Al-Marzouqi, M. and Duidar, A. (2012). Effect of PVDF concentration on the morphology and performance of hollow fiber membrane employed as gas-liquid membrane contactor for $\mathrm{CO}_{2}$ absorption. Separation and Purification Technology, 98: $174-185$.

13. Amirilargani, M., Saljoughi, E. and Mohammadi, T. (2009). Effects of Tween 80 concentration as a surfactant additive on morphology and permeability of flat sheet Polyethersulfone (PES) membranes. Desalination, 249: $837-842$. 